Check for updates

Cite this: Chem. Commun., 2017, 53,6768

Received 4th May 2017,

Accepted 31st May 2017

DOI: $10.1039 / c 7 c c 03469 e$

rsc.li/chemcomm

\section{To cage or to be caged? The cytotoxic species in ruthenium-based photoactivated chemotherapy is not always the metal $\dagger$}

\author{
Jordi-Amat Cuello-Garibo, Michael S. Meijer and Sylvestre Bonnet (D) *
}

In metal-based photoactivated chemotherapy (PACT), two photoproducts are generated by light-triggered photosubstitution of a metal-bound ligand: the free ligand itself and an aquated metal complex. By analogy with cisplatin, the aquated metal complex is usually presented as the biologically active species, as it can typically bind to DNA. In this work, we show that this qualitative assumption is not necessarily valid by comparing the biological activity, $\log P$, and cellular uptake of three ruthenium-based PACT complexes: $\left[R u(b p y)_{2}(d m b p y)\right]^{2+},\left[R u(b p y)_{2}(m t m p)\right]^{2+}$, and $\left[R u\left(P_{2} \text { phen }\right)_{2}(m t m p)\right]^{2+}$. For the first complex, the photoreleased dmbpy ligand is responsible for the observed phototoxicity, whereas the second complex is not phototoxic, and for the third complex it is the ruthenium bis-aqua photoproduct that is the sole cytotoxic species.

Ruthenium polypyridyl complexes are well known for their versatile and tunable photophysical and photochemical properties. ${ }^{1}$ In recent years, they have attracted much interest for molecular imaging and photopharmacology, ${ }^{2}$ and in particular for photodynamic Therapy (PDT) and photoactivated chemotherapy (PACT). ${ }^{3}$ In PACT like in PDT, a non-toxic or poorly cytotoxic prodrug becomes much more cytotoxic upon light irradiation, allowing for a time- and spatially-resolved delivery of the toxicity of the anticancer drug. However, whereas in PDT the photocytotoxicity relies on the photochemical generation of reactive oxygen species (ROS) such as singlet oxygen $\left({ }^{1} \mathrm{O}_{2}\right)$, in PACT a photochemical bond-breaking reaction occurs, which for coordination compounds is often realized via the photosubstitution of one of the ligands by water molecules. ${ }^{4}$ To make PACT rutheniumbased compounds, $\left[\mathrm{Ru}(\mathrm{bpy})_{3}\right]^{2+}$-like complexes must be modified so that the triplet metal-centered excited states $\left({ }^{3} \mathrm{MC}\right)$ come in close proximity to the triplet metal-to-ligand charge transfer states $\left({ }^{3} \mathrm{MLCT}\right) .{ }^{5}$ Such modification typically entails the use of sterically hindered bidentate ligands such as

Leiden Institute of Chemistry, University of Leiden, Einsteinweg 55, 2333 CC,

Leiden, The Netherlands.E-mail: bonnet@chem.leidenuniv.nl

$\dagger$ Electronic supplementary information (ESI) available: Synthetic procedures, singlet oxygen quantum yield, partition coefficient and cellular uptake measurements, cell culture and $\mathrm{EC}_{50}$ (photo)cytotoxicity assays. See DOI: 10.1039/c7cc03469e 6,6'-dimethyl-2,2'-bipyridine (dmbpy) and its derivatives. ${ }^{6}$ For example, the irradiation of $\left[\mathrm{Ru}(\mathrm{bpy})_{2}(\mathrm{dmbpy})\right]^{2+}$ in water (bpy $=2,2^{\prime}$-bipyridine) leads to the photosubstitution of dmbpy by two water molecules, generating the aquated species cis$\left[\mathrm{Ru}(\mathrm{bpy})_{2}\left(\mathrm{OH}_{2}\right)_{2}\right]^{2+}$ (Scheme 1) that was shown to bind to plasmid DNA. ${ }^{7}$ When performed in the presence of growing cancer cells, this photoreaction clearly leads to photocytotoxicity, which many have interpreted as a consequence of the cytotoxicity of cis-[Ru(bpy $\left.)_{2}\left(\mathrm{OH}_{2}\right)_{2}\right]^{2+}$, by analogy to the cytotoxic aquated form of cisplatin, cis-[Pt $\left.\left(\mathrm{NH}_{3}\right)_{2}\left(\mathrm{OH}_{2}\right)_{2}\right]^{2+}$. On the other hand, many ruthenium polypyridyl complexes have been used as photocaging groups for neurotransmitters and organic enzyme inhibitors, ${ }^{8}$ for which the absence of acute toxicity is a pre-requisite. The parent compound $\left[\mathrm{Ru}(\mathrm{bpy})_{2} \mathrm{Cl}_{2}\right]$, which thermally hydrolyzes into cis$\left[\mathrm{Ru}(\mathrm{bpy})_{2}\left(\mathrm{OH}_{2}\right)_{2}\right]^{2+}$, was shown by the group of Reedijk not to be cytotoxic. ${ }^{9}$ As several groups have developed analogues of $\left[\mathrm{Ru}(\mathrm{bpy})_{2}(\mathrm{dmbpy})\right]^{2+}$ for developing new PACT compounds, we asked ourselves which photoproduct, from the two that are formed upon light irradiation, actually is cytotoxic enough to kill cancer cells: the cis bis-aqua ruthenium complex or the free ligand?

To address this question, we compared the known compound $\left[\mathrm{Ru}(\mathrm{bpy})_{2}(\mathrm{dmbpy})\right] \mathrm{Cl}_{2}\left([\mathbf{1}] \mathrm{Cl}_{2}\right)$ with a new photoactive

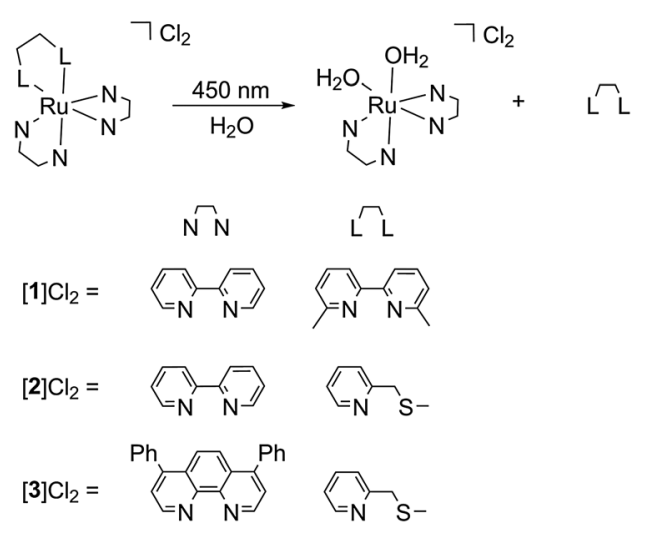

Scheme 1 Chemical structures of PACT ruthenium compounds $[1] \mathrm{Cl}_{2}-[3] \mathrm{Cl}_{2}$ and their reaction upon blue light irradiation in water. 
compound $\left[\mathrm{Ru}(\mathrm{bpy})_{2}(\mathrm{mtmp})\right] \mathrm{Cl}_{2}\left([2] \mathrm{Cl}_{2}\right)$ containing the bidentate chelate 2-methylthiomethylpyridine ( $\mathrm{mtmp}){ }^{7}$ Thioethers are soft enough to coordinate well to ruthenium(II) in the ground state, but they can be photosubstituted more efficiently than pyridines due to the relative weakness of the Ru-S bond in the excited state, compared to Ru-N bonds. ${ }^{10}$ Indeed when a solution of [2] $\mathrm{Cl}_{2}$ is irradiated with blue light (445 nm), a shift of the ${ }^{1} \mathrm{MLCT}$ absorption maximum from 432 to $491 \mathrm{~nm}$ was observed, as well as two consecutive isosbestic points at 439 and $458 \mathrm{~nm}$ (Fig. 1a). Mass spectrometry after 50 minutes of irradiation (Fig. S1, ESI $\dagger$ ) showed peaks at 140.2, 225.0, and 448.1 which corresponded to $\{\mathrm{mtmp}+\mathrm{H}\}^{+}$(calc. $\left.m / z=140.2\right),\left[\mathrm{Ru}(\text { bpy })_{2}\left(\mathrm{OH}_{2}\right)_{2}\right]^{2+}($ calc. $m / z=$ 225.0), and $\left[\mathrm{Ru}(\mathrm{bpy})_{2}\left(\mathrm{OH}_{2}\right)(\mathrm{OH})\right]^{+}$(calc. $\left.m / z=448.5\right)$, respectively. Thus, $[2]^{2+}$ like $[\mathbf{1}]^{2+}$ leads upon light irradiation to the formation of the bis-aqua complex cis-[Ru(bpy $\left.)_{2}\left(\mathrm{OH}_{2}\right)_{2}\right]^{2+}$, but the free ligand obtained as the second photoproduct is $\mathrm{mtmp}$, instead of dmbpy with $[\mathbf{1}] \mathrm{Cl}_{2}$ (Scheme 1). The two sequential isosbestic points observed by UV-vis during the irradiation of $[2] \mathrm{Cl}_{2}$ suggest that photosubstitution takes place in a two-step process. The first process is very fast (it was completed within the first 30 seconds of irradiation) and is assumed to be the photosubstitution of one coordination bond of $\mathrm{mtmp}$ by a single water molecule. The second photosubstitution is much slower, as usually reported ${ }^{11}$ and leads to the final photoproducts $\mathrm{mtmp}$ and cis-[Ru(bpy $\left.)_{2}\left(\mathrm{OH}_{2}\right)_{2}\right]^{2+}$. The quantum yield of this second process $\left(\Phi_{\mathrm{PR}}\right)$ was 0.0030 according to Glotaran global fitting (see the ESI $\dagger$ ).

The cytotoxicities of the free ligands dmbpy and mtmp were first compared in an A549 lung cancer cell line (adenocarcinomic human alveolar basal epithelial cells). Both organic ligands are rather lipophilic, as demonstrated by the octanol/water partition coefficient values $(\log P)$ of +3.29 and +1.63 for dmbpy and $\mathrm{mtmp}$, respectively (Table 2). Both ligands are therefore expected to be taken up at least passively by the cells. The cell growth inhibition effective concentrations $\left(\mathrm{EC}_{50}\right)$, i.e. the compound concentration at which the cell viability was reduced by $50 \%$ compared to the non-treated control, were measured following a protocol adapted from Hopkins et al. (see the ESI $\dagger$ ). ${ }^{12}$ Clearly, dmbpy was found to be cytotoxic, with $\mathrm{EC}_{50}$ values of 8.7 and $6.5 \mu \mathrm{M}$ in the dark and upon light irradiation, respectively (Fig. 2 and Table 1), whereas no cytotoxicity was observed for mtmp up to $200 \mu \mathrm{M}$. Although cellular localization of chemicals may differ whether they are simply incubated with the cells or
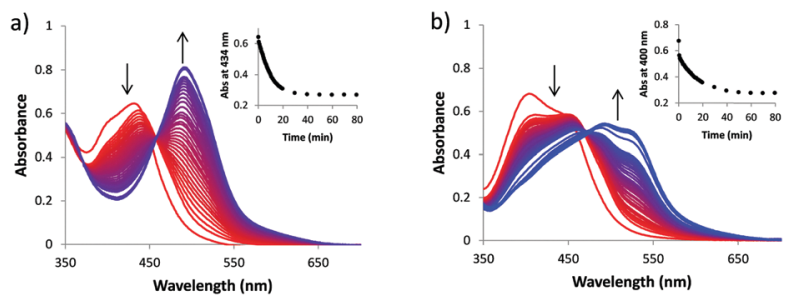

Fig. 1 Evolution of the UV-vis absorption spectra of a solution of (a) [2] $\mathrm{Cl}_{2}$ and (b) $[3] \mathrm{Cl}_{2}$ in water upon irradiation with a $445 \mathrm{~nm}$ LED under $\mathrm{N}_{2}$ at $25^{\circ} \mathrm{C}$. Conditions: (a) $80 \mathrm{~min}, 0.109 \mathrm{mM}$, and $15.50 \mathrm{~mW} \mathrm{~cm}^{-2}$; (b) $80 \mathrm{~min}$, $0.038 \mathrm{mM}$, and $13.65 \mathrm{~mW} \mathrm{~cm}^{-2}$.

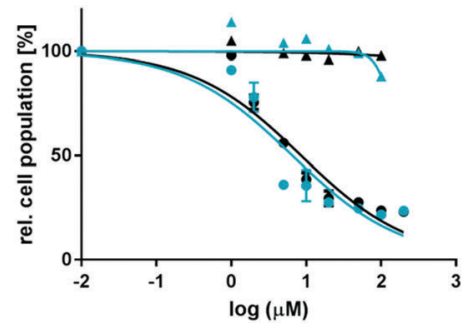

Fig. 2 Dose-response curves for A549 cells incubated with dmbpy (circles) or mtmp (triangles) and irradiated for $10 \mathrm{~min}$ with blue light $(455 \mathrm{~nm}$, $6.5 \mathrm{~J} \mathrm{~cm}^{-2}$ ) $6 \mathrm{~h}$ after treatment (blue data points), or left in the dark (black data points). Phototoxicity assay outline: cells seeded at $5 \times 103$ cells per well at $t=0 \mathrm{~h}$, treated with dmbpy or mtmp at $t=24 \mathrm{~h}$, irradiated at $t=30 \mathrm{~h}$, and SRB cell-counting assay performed at $t=96 \mathrm{~h}$. Incubation conditions: $37^{\circ} \mathrm{C}$ and $7 \% \mathrm{CO}_{2}$.

generated inside the cells upon light irradiation of a prodrug such as $[1] \mathrm{Cl}_{2}$, this result suggests that the photocytotoxicity reported for $[1] \mathrm{Cl}_{2}$ may be at least partly due to the release of the dmbpy ligand.

In a second step, the $\mathrm{EC}_{50}$ values of complexes $[1] \mathrm{Cl}_{2}$ and [2] $\mathrm{Cl}_{2}$ were measured in A549 cells, both in the dark and upon blue light irradiation, and following the same protocol applied for the free ligand (Table 1). The selected light dose $\left(6.5 \mathrm{~J} \mathrm{~cm}^{-2}\right)$ guarantees that no toxic effect for the cells occurs due to the irradiation itself. ${ }^{12}$ At that light dose, both $[1] \mathrm{Cl}_{2}$ and $[2] \mathrm{Cl}_{2}$ are fully activated below $40 \mu \mathrm{M}$ (see Fig. S4 and ESI $\dagger$ ). As shown in Fig. 3, no significant decrease in the cell population was observed after treatment with less than $100 \mu \mathrm{M}$ of complex $[1] \mathrm{Cl}_{2}$ or $[2] \mathrm{Cl}_{2}$ in the dark (Table 1). Thus, these species can be considered to be essentially non-cytotoxic in the dark. After blue light irradiation, an $\mathrm{EC}_{50}$ value of $10.9 \mu \mathrm{M}$ was found for [1] $\mathrm{Cl}_{2}$, corresponding to a photoindex of 19, which qualitatively fits the data reported by Glazer et al. on this compound. ${ }^{7}$ However, no phototoxicity was observed for $[2] \mathrm{Cl}_{2}$, in spite of the fact that this compound also delivers the $c i s-\left[\mathrm{Ru}(\mathrm{bpy})_{2}\left(\mathrm{OH}_{2}\right)_{2}\right]^{2+}$ species upon irradiation.

In order to explain these differences, the octanol/water partition coefficient $\left(\log P\right.$ value; see the $\left.\operatorname{ESI}^{13}{ }^{13}\right)$, the cellular uptake, and the quantum yield for singlet oxygen generation were measured for both complexes (Table 2). $\log P$ values of -1.42 and -1.33 were found for $[1] \mathrm{Cl}_{2}$ and $[2] \mathrm{Cl}_{2}$, respectively, which means that both complexes have similar hydrophilicities and are not prone to enter the cell by passive diffusion through the membrane. As expected from these high hydrophilicity values, the cellular uptake before light activation, measured by ICP-MS by incubating A549 cells with $[1] \mathrm{Cl}_{2}$ or $[2] \mathrm{Cl}_{2}$ at 20 and $80 \mu \mathrm{M}$, respectively, for $6 \mathrm{~h}$ in the dark, was found to be very low: 1.32 and $1.27 \mathrm{ng}$ of ruthenium were found per million cells for $[1] \mathrm{Cl}_{2}$ and $[2] \mathrm{Cl}_{2}$, respectively, compared to values usually found above 10-20 ng Ru per $10^{6}$ cells for compounds that are well taken up. ${ }^{14}$ Thus, the higher cytotoxicity found for $[\mathbf{1}] \mathrm{Cl}_{2}$ after light activation cannot be attributed to a higher uptake of the complex prior to irradiation.

Many published phototherapeutic ruthenium complexes are excellent PDT agents, i.e., they generate ${ }^{1} \mathrm{O}_{2}$ via energy transfer from the ${ }^{3}$ MLCT to molecular oxygen present in the cells. ${ }^{15}$ 
Table 1 Cancer cell growth inhibition effective concentrations ( $\mathrm{EC}_{50}$ values with $95 \%$ confidence interval in $\mu \mathrm{M}$ ), in the dark and upon blue light irradiation $\left(6.5 \mathrm{~J} \mathrm{~cm}^{-2}\right)$, for $[1] \mathrm{Cl}_{2},[2] \mathrm{Cl}_{2},[3] \mathrm{Cl}_{2}, \mathrm{dmbpy}$, and mtmp on lung cancer cells (A549); photoindices (PIs) defined as $\mathrm{EC}_{50, \text { dark }} / \mathrm{EC}_{50, \text { light }}$

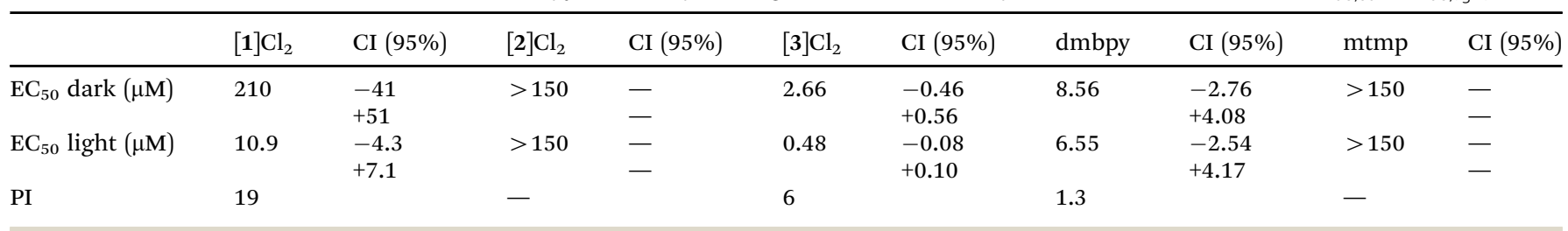

a)

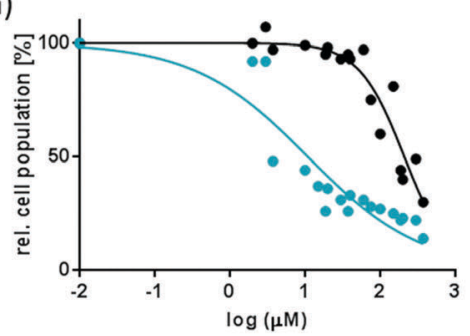

b)

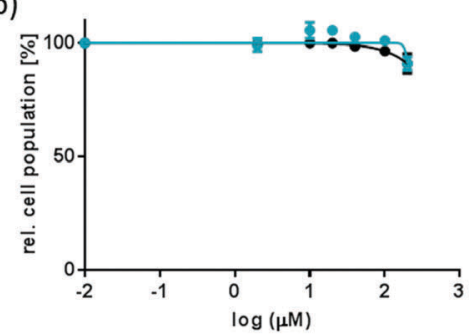

c)

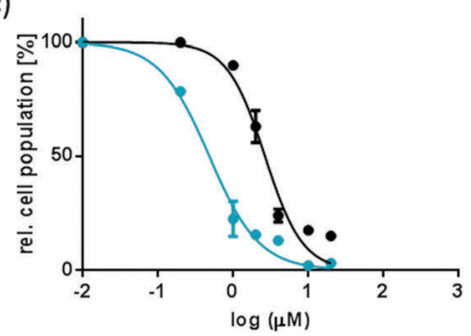

Fig. 3 Dose-response curves for A549 cells incubated with [1] $\mathrm{Cl}_{2}$ (a), [2] $\mathrm{Cl}_{2}$ (b), or [3] $\mathrm{Cl}_{2}$ (c) and irradiated for 10 min with blue light (455 $\mathrm{nm}, 6.5 \mathrm{~J} \mathrm{~cm}{ }^{-2}$ ) $6 \mathrm{~h}$ after treatment (blue data points), or left in the dark (black data points). Phototoxicity assay outline: cells seeded at $5 \times 10^{3}$ cells per well at $t=0 \mathrm{~h}$, treated with $[1] \mathrm{Cl}_{2},[2] \mathrm{Cl}_{2}$, or $[3] \mathrm{Cl}_{2}$ at $t=24 \mathrm{~h}$, irradiated at $t=30 \mathrm{~h}$, and SRB assay performed at $t=96 \mathrm{~h}$. Incubation conditions: $37{ }^{\circ} \mathrm{C}$ and $7 \% \mathrm{CO}_{2}$.

Table 2 Partition coefficient (log $P$ values), singlet oxygen generation quantum yields $\left(\Phi_{\Delta}\right)$, and cellular uptake of $[\mathbf{1}] \mathrm{Cl}_{2},[\mathbf{2}] \mathrm{Cl}_{2},[\mathbf{3}] \mathrm{Cl}_{2}$, dmbpy, and $m \mathrm{mtmp}$

\begin{tabular}{|c|c|c|c|c|c|}
\hline$\Phi_{\Delta}$ & 0.023 & $<0.005$ & 0.02 & - & - \\
\hline
\end{tabular}

Although it is commonly admitted that photosubstitutionally labile ruthenium complexes are poor singlet oxygen generators, the experimental values of ${ }^{1} \mathrm{O}_{2}$ generation quantum yields $\left(\Phi_{\Delta}\right)$ are very rare in the literature for PACT compounds. In order to rule out that $[\mathbf{1}] \mathrm{Cl}_{2}$ and $[2] \mathrm{Cl}_{2}$ may act as PDT agents, $\Phi_{\Delta}$ values were experimentally determined for both complexes under blue light irradiation $(450 \mathrm{~nm})$, by direct detection of the $1274 \mathrm{~nm}$ infrared phosphorescence of ${ }^{1} \mathrm{O}_{2}$ in $\mathrm{CD}_{3} \mathrm{OD}$. $\Phi_{\Delta}$ values of 0.023 and $<0.005$ were found for $[1] \mathrm{Cl}_{2}$ and $[2] \mathrm{Cl}_{2}$, respectively, using $\left[\mathrm{Ru}(\mathrm{bpy})_{3}\right] \mathrm{Cl}_{2}$ as a reference $\left(\Phi_{\Delta}=0.73\right) .{ }^{16}$ Thus, since both complexes are mediocre photosensitizers for ${ }^{1} \mathrm{O}_{2}$, the phototoxicity of $[1] \mathrm{Cl}_{2}$ cannot be a photodynamic effect.

To summarize, $[1] \mathrm{Cl}_{2}$ and $[2] \mathrm{Cl}_{2}$ have similar negative $\log P$ values, similarly low cellular uptake after $6 \mathrm{~h}$ incubation in the dark, similarly low ${ }^{1} \mathrm{O}_{2}$ generation quantum yields, and they both form $\left[\mathrm{Ru}(\mathrm{bpy})_{2}\left(\mathrm{OH}_{2}\right)_{2}\right]^{2+}$ upon light irradiation. Their main difference is that they photochemically release either dmbpy or mtmp, respectively. Meanwhile, we also demonstrated three points. First, the light activation of $[\mathbf{1}] \mathrm{Cl}_{2}$ resulted in a 19-fold lower $\mathrm{EC}_{50}$ value compared to that obtained in the dark, whereas the light irradiation of $[2] \mathrm{Cl}_{2}$ does not influence an already negligible cytotoxicity. Second, dmbpy is cytotoxic to A549 cells, whereas mtmp is not. Third, the $\mathrm{EC}_{50}$ value of $[\mathbf{1}] \mathrm{Cl}_{2}$ after irradiation $(10.9 \mu \mathrm{M})$ is close, in the same protocol, to the $\mathrm{EC}_{50}$ value found for dmbpy $(6.6 \mu \mathrm{M})$. Altogether, these results strongly suggest that the phototoxicity observed with complex $[1] \mathrm{Cl}_{2}$ is caused by the dmbpy ligand that is photoreleased and taken up after extra-cellular activation, rather than by the $c i s-\left[\mathrm{Ru}(\mathrm{bpy})_{2}\left(\mathrm{OH}_{2}\right)_{2}\right]^{2+}$ species. In other words, $\left[\mathrm{Ru}(\mathrm{bpy})_{2}\left(\mathrm{OH}_{2}\right)_{2}\right]^{2+}$ is a photocaging group for the cytotoxic dmbpy ligand, rather than the reverse!

These surprising results do not, in our eyes, discredit the concept of ruthenium-based PACT. The problem of compounds such as $[1] \mathrm{Cl}_{2}$ or $[2] \mathrm{Cl}_{2}$ is only that their ruthenium-based photoproduct, cis- $\left[\mathrm{Ru}(\mathrm{bpy})_{2}\left(\mathrm{OH}_{2}\right)_{2}\right]^{2+}$, is not lipophilic enough to cross membranes and cause significant damage inside the cells. To demonstrate this idea, we synthesized a much more lipophilic version of compound $[2] \mathrm{Cl}_{2}$, i.e., $\left[\mathrm{Ru}\left(\mathrm{Ph}_{2} \text { phen }\right)_{2}(\mathrm{mtmp})\right] \mathrm{Cl}_{2}\left([3] \mathrm{Cl}_{2}\right.$, $\mathrm{Ph}_{2}$ phen $=4,7$-diphenyl-1,10-phenanthroline, see Scheme 1), by reacting $\left[\mathrm{Ru}\left(\mathrm{Ph}_{2} \text { phen }\right)_{2} \mathrm{Cl}_{2}\right]$ with $\mathrm{mtmp}$ in ethylene glycol at $115{ }^{\circ} \mathrm{C}$ (see the ESI $\dagger$ ). $[3] \mathrm{Cl}_{2}$ has a much higher $\log P$ value of 0.28 , as expected from the more lipophilic $\mathrm{Ph}_{2}$ phen spectator ligands. The photoreactivity of $[3] \mathrm{Cl}_{2}$ in water under blue light irradiation $(445 \mathrm{~nm})$ is similar to that of $[2] \mathrm{Cl}_{2}$ : a shift of the ${ }^{1} \mathrm{MLCT}$ absorption maximum from 404 to $492 \mathrm{~nm}$ and two sequential isosbestic points at 447 and $472 \mathrm{~nm}$ were observed (Fig. 1b). Mass spectrometry after $70 \mathrm{~min}$ of irradiation (Fig. S1b, ESI $\dagger$ ) also showed photosubstitution of the non-toxic mtmp ligand, with peaks at $140.2,412.3$, and 424.5 , corresponding to $\{\mathrm{mtmp}+\mathrm{H}\}^{+},\left[\mathrm{Ru}\left(\mathrm{Ph}_{2} \text { phen }\right)_{2}(\mathrm{MeCN})\left(\mathrm{OH}_{2}\right)\right]^{2+}$ (calc. $\left.m / z=412.6\right)$, and $\left[\mathrm{Ru}\left(\mathrm{Ph}_{2} \text { phen }\right)_{2}(\mathrm{MeCN})_{2}\right]^{2+}$ (calc. $m / z=424.1$ ), respectively. The last two species are formed in the mass spectrometer and demonstrate the photochemical formation of the bis-aqua 
photoproduct $\left[\mathrm{Ru}\left(\mathrm{Ph}_{2} \text { phen }\right)_{2}\left(\mathrm{OH}_{2}\right)_{2}\right]^{2+}$. The photosubstitution has a quantum yield of 0.0010 , slightly lower than that found for $[2] \mathrm{Cl}_{2}$, and the ${ }^{1} \mathrm{O}_{2}$ generation quantum yield was similar to that found for $[1] \mathrm{Cl}_{2}$ (i.e., $\Phi_{\Delta}=0.020$; see Table 2). Thus, $[3] \mathrm{Cl}_{2}$ is a bad PDT sensitizer but a good PACT compound, as like $[2] \mathrm{Cl}_{2}$ it photosubstitutes the non-toxic mtmp ligand to deliver $\left[\mathrm{Ru}\left(\mathrm{Ph}_{2} \text { phen }\right)_{2}\left(\mathrm{OH}_{2}\right)_{2}\right]^{2+}$, a lipophilic analogue of $\left[\mathrm{Ru}(\mathrm{bpy})_{2}\left(\mathrm{OH}_{2}\right)_{2}\right]^{2+}$. In A549 cells, [3] $\mathrm{Cl}_{2}$ had a higher cytotoxicity in the dark $\left(\mathrm{EC}_{50}=2.66 \mu \mathrm{M}\right)$, as expected from its higher lipophilicity. Critically, the $\mathrm{EC}_{50}$ value decreased 6-fold down to $0.48 \mu \mathrm{M}$ under a blue light dose of $6.5 \mathrm{~J} \mathrm{~cm}^{-2}$. Such increased cytotoxicity can, this time, only be attributed to the photochemical generation of $\left[\mathrm{Ru}\left(\mathrm{Ph}_{2} \text { phen }\right)_{2}\left(\mathrm{OH}_{2}\right)_{2}\right]^{2+}$, as the second photoproduct, mtmp, is non-toxic. [3] $\mathrm{Cl}_{2}$ is thus a true metal-based PACT compound where the toxicity of the Ru-based aqua species is "caged" via coordination of the mtmp ligand. Overall, our results demonstrate that determining which photoproduct is the cytotoxic species is not straightforward, as factors such as ligand toxicity, lipophilicity of the prodrug, cellular uptake and localization, and/or singlet oxygen generation may all influence the phototoxicity of a given compound. Although we have demonstrated here that the phototoxicity of $[\mathbf{1}] \mathrm{Cl}_{2}$ is not due to the ruthenium-based photoproduct but because of the released dmbpy ligand, that of compound $[3] \mathrm{Cl}_{2}$ demonstrates that PACT compounds where the $\mathrm{Ru}$ photoproduct bears the toxic load can be made, provided its lipophilicity is high enough for the compound to enter the cell.

The European Research Council is acknowledged for a Starting Grant to S. B. The Dutch Organization for Scientific Research (NWO) is acknowledged for a VIDI grant to S. B. Prof. Elisabeth Bouwman is kindly acknowledged for scientific discussion and support. The COST actions CM1105 "Functional metal complexes that bind to biomolecules" is acknowledged for stimulating scientific discussion.

\section{References}

1 (a) V. Balzani, G. Bergamini, F. Marchioni and P. Ceroni, Coord. Chem. Rev., 2006, 250, 1254-1266; (b) S. Campagna, F. Puntoriero, F. Nastasi, G. Bergamini and V. Balzani, Photochemistry and Photophysics of Coordination Compounds: Ruthenium, Topics in Current Chemistry, Springer-Verlag Berlin, Heidelberg, 2007, vol. 280, pp. 117-214; (c) E. Baranoff, J. Collin, J. Furusho, Y. Furusho, A. Laemmel and J. Sauvage, Inorg. Chem., 2002, 41, 1215-1222; (d) E. Baranoff, J.-P. Collin, Y. Furusho, A.-C. Laemmel and J.-P. Sauvage, Chem. Commun., 2000, 1935-1936.
2 (a) V. Fernandez-Moreira, F. L. Thorp-Greenwood and M. P. Coogan, Chem. Commun., 2010, 46, 186-202; (b) A. Martin, A. Byrne, C. S. Burke, R. J. Forster and T. E. Keyes, J. Am. Chem. Soc., 2014, 136, 15300-15309; (c) M. R. Gill, J. Garcia-Lara, S. J. Foster, C. Smythe, G. Battaglia and J. A. Thomas, Nat. Chem., 2009, 1, 662-667.

3 (a) C. Mari, V. Pierroz, S. Ferrari and G. Gasser, Chem. Sci., 2015, 6, 2660-2686; (b) M. Frasconi, Z. Liu, J. Lei, Y. Wu, E. Strekalova, D. Malin, M. W. Ambrogio, X. Chen, Y. Y. Botros, V. L. Cryns, J.-P. Sauvage and J. F. Stoddart, J. Am. Chem. Soc., 2013, 135, 11603-11613.

4 (a) R. N. Garner, J. C. Gallucci, K. R. Dunbar and C. Turro, Inorg. Chem., 2011, 50, 9213-9215; (b) B. A. Albani, B. Peña, N. A. Leed, N. A. B. G. de Paula, C. Pavani, M. S. Baptista, K. R. Dunbar and C. Turro, J. Am. Chem. Soc., 2014, 136, 17095-17101.

5 (a) A.-C. Laemmel, J.-P. Collin and J.-P. Sauvage, Eur. J. Inorg. Chem., 1999, 383-386; (b) L. Salassa, C. Garino, G. Salassa, R. Gobetto and C. Nervi, J. Am. Chem. Soc., 2008, 130, 9590-9597.

6 (a) T. Sainuddin, M. Pinto, H. Yin, M. Hetu, J. Colpitts and S. A. McFarland, J. Inorg. Biochem., 2016, 158, 45-54; (b) K. T. Hufziger, F. S. Thowfeik, D. J. Charboneau, I. Nieto, W. G. Dougherty, W. S. Kassel, T. J. Dudley, E. J. Merino, E. T. Papish and J. J. Paul, J. Inorg. Biochem., 2014, 130, 103-111.

7 B. S. Howerton, D. K. Heidary and E. C. Glazer, J. Am. Chem. Soc., 2012, 134, 8324-8327.

8 (a) O. Filevich, M. Salierno and R. Etchenique, J. Inorg. Biochem., 2010, 104, 1248-1251; (b) L. Zayat, O. Filevich, L. M. Baraldo and R. Etchenique, Philos. Trans. R. Soc., A, 2013, 371, 20120330; (c) N. Karaoun and A. K. Renfrew, Chem. Commun., 2015, 51, 14038-14041; (d) T. Respondek, R. Sharma, M. K. Herroon, R. N. Garner, J. D. Knoll, E. Cueny, C. Turro, I. Podgorski and J. J. Kodanko, ChemMedChem, 2014, 9, 1306-1315; (e) N. A. Smith, P. Zhang, S. E. Greenough, M. D. Horbury, G. J. Clarkson, D. McFeely, A. Habtemariam, L. Salassa, V. G. Stavros, C. G. Dowson and P. J. Sadler, Chem. Sci., 2017, 8, 395-404.

9 O. Novakova, J. Kasparkova, O. Vrana, P. M. Vanvliet, J. Reedijk and V. Brabec, Biochemistry, 1995, 34, 12369-12378.

10 R. N. Garner, L. E. Joyce and C. Turro, Inorg. Chem., 2011, 50, 4384-4391. 11 D. V. Pinnick and B. Durham, Inorg. Chem., 1984, 23, 1440-1445.

12 S. L. Hopkins, B. Siewert, S. H. C. Askes, P. Veldhuizen, R. Zwier, M. Heger and S. Bonnet, Photochem. Photobiol. Sci., 2016, 15, 644-653.

13 F. Wang, J. Xu, A. Habtemariam, J. Bella and P. J. Sadler, J. Am. Chem. Soc., 2005, 127, 17734-17743.

14 (a) V. H. S. van Rixel, B. Siewert, S. L. Hopkins, S. H. C. Askes, A. Busemann, M. A. Siegler and S. Bonnet, Chem. Sci., 2016, 7, 4922-4929; (b) Y. Fu, C. Sanchez-Cano, R. Soni, I. Romero-Canelon, J. M. Hearn, Z. Liu, M. Wills and P. J. Sadler, Dalton Trans., 2016, 45, $8367-8378$

15 (a) C. Mari, V. Pierroz, R. Rubbiani, M. Patra, J. Hess, B. Spingler, L. Oehninger, J. Schur, I. Ott, L. Salassa, S. Ferrari and G. Gasser, Chem. - Eur. J., 2014, 20, 14421-14436; (b) A. Frei, R. Rubbiani, S. Tubafard, O. Blacque, P. Anstaett, A. Felgentrager, T. Maisch, L. Spiccia and G. Gasser, J. Med. Chem., 2014, 57, 7280-7292; (c) G. Shi, S. Monro, R. Hennigar, J. Colpitts, J. Fong, K. Kasimova, H. Yin, R. DeCoste, C. Spencer, L. Chamberlain, A. Mandel, L. Lilge and S. A. McFarland, Coord. Chem. Rev., 2015, 282-283, 127-138.

16 D. Garcia-Fresnadillo, Y. Georgiadou, G. Orellana, A. M. Braun and E. Oliveros, Helv. Chim. Acta, 1996, 79, 1222-1238. 